\title{
Lab-Scale Carbonation of Wood Ash for $\mathrm{CO}_{2}$-Sequestration
}

\author{
Robin Koch ${ }^{1}\left(\mathbb{D}\right.$, Gregor Sailer ${ }^{1, *}$, Sebastian Paczkowski ${ }^{2}$, Stefan Pelz ${ }^{1} \mathbb{D}$, Jens Poetsch ${ }^{1}$ and Joachim Müller ${ }^{3}(\mathbb{D}$ \\ 1 Department of Bioenergy, University of Applied Forest Sciences Rottenburg, Schadenweilerhof, 72108 Rottenburg, \\ Germany; r.koch96@gmx.net (R.K.); pelz@hs-rottenburg.de (S.P.); poetsch@hs-rottenburg.de (J.P.) \\ 2 Department of Forest Work Science and Engineering, Faculty of Forest Sciences and Forest Ecology, \\ University of Göttingen, Büsgenweg 4, 37077 Göttingen, Germany; sebastian.paczkowski@uni-goettingen.de \\ 3 Tropics and Subtropics Group, Institute of Agricultural Engineering, University of Hohenheim, Garbenstrasse 9, \\ 70599 Stuttgart, Germany; joachim.mueller@uni-hohenheim.de \\ * Correspondence: sailer@hs-rottenburg.de
}

Citation: Koch, R.; Sailer, G.; Paczkowski, S.; Pelz, S.; Poetsch, J.; Müller, J. Lab-Scale Carbonation of Wood Ash for $\mathrm{CO}_{2}$-Sequestration. Energies 2021, 14, 7371. https:// doi.org/10.3390/en14217371

Academic Editor: Francesco Frusteri

Received: 7 October 2021

Accepted: 2 November 2021

Published: 5 November 2021

Publisher's Note: MDPI stays neutral with regard to jurisdictional claims in published maps and institutional affiliations.

Copyright: (c) 2021 by the authors. Licensee MDPI, Basel, Switzerland. This article is an open access article distributed under the terms and conditions of the Creative Commons Attribution (CC BY) license (https:/ / creativecommons.org/licenses/by/ $4.0 /)$.

\begin{abstract}
This study evaluated the $\mathrm{CO}_{2}$ sequestration potential with combustion ashes in the aqueous phase. The aim was to provide a cost-effective carbon sequestration method for combustion unit operators (flue gas cleaning) or biogas producers (biogas upgrading). Therefore, two separate test series were executed to identify the carbonation efficiency (CE) of bottom wood ash (1) at different mixing ratios with water in batch experiments and (2) under dynamic flow conditions. It was furthermore evaluated whether subsequent use of the carbonated wood ash for soil amendment could be possible and whether the process water could be passed into the sewage. The batch test series showed that different mixing ratios of wood ash and water had an influence on the CE. The flow series showed that the mean CE varied between approximately $14 \%$ and $17 \%$. Thus, the ash proved to be suitable for carbonation processes. The process water was dischargeable, and the carbonated wood ash has potential for chalking, as no legal thresholds were exceeded. Therefore, wood ash carbonation could be used as a low-tech $\mathrm{CO}_{2}$ sequestration technology. Compared to existing energy consuming and cost intensive carbon capture and storage technologies, sequestration with ash could be beneficial, as it represents a low-tech approach.
\end{abstract}

Keywords: carbon capture and storage (CCS); biogas upgrading; combustion; anaerobic digestion; calcium oxide; fertilizers; flue gas

\section{Introduction}

Climate change will be one of the biggest challenges to face in the 21st century [1]. To tackle upcoming problems, the European Commission proposed the European Green Deal focussing on greenhouse gas neutrality. Anthropogenic $\mathrm{CO}_{2}$ is one of the main drivers for the projected climate change, but reducing $\mathrm{CO}_{2}$ emissions is not enough to tackle this challenge. Furthermore, the $\mathrm{CO}_{2}$ that has already been emitted needs to be captured and stored, leading to nearly the same impact as reducing the emissions [2]. Therefore, one important aspect in reaching greenhouse gas neutrality is sequestration of $\mathrm{CO}_{2}$ from exhaust gases from industrial applications or heat and power plants. Possible approaches for binding $\mathrm{CO}_{2}$ are reforestation and carbon capture storage (CCS) or bioenergy CCS technologies (BECCS) [3,4].

One CCS method comprises $\mathrm{CO}_{2}$ storage in former oil or gas deposits with an impermeable cap rock under high pressure. Disadvantages of this method are high energy consumption to compress the $\mathrm{CO}_{2}$ and the need for special geological formations [5]. Further CCS methods and their advantages and disadvantages are reviewed by Geden et al. [6]. For example, bringing biochar into the soil increases soil fertility. However, there might be usage competition with food production, which was also stated by Smith [7]. Another alternative reviewed by Geden et al. [6] and Muratori et al. [8] is BECCS, which is technically simpler but might reduce biodiversity and might emit other greenhouse gases, such as $\mathrm{N}_{2} \mathrm{O}$. A feasible addition to the existing CCS methods is the direct sequestration 
of $\mathrm{CO}_{2}$ from exhaust gases by carbonating combustion ashes [9]. According to Stark and Wicht [10], carbonation processes can be simplified, as shown in Equation (1). The main reaction partners are $\mathrm{Ca}(\mathrm{OH})_{2}$ and $\mathrm{CO}_{2}$ in an aqueous medium, but the same reaction mechanism occurs with other hydroxides, e.g., $\mathrm{KOH}$ and $\mathrm{NaOH}$, as well.

$$
\mathrm{Ca}(\mathrm{OH})_{2}+\mathrm{H}_{2} \mathrm{O}+\mathrm{CO}_{2} \rightarrow \mathrm{CaCO}_{3}+2 \mathrm{H}_{2} \mathrm{O}
$$

In general, the availability of alkali hydroxides promotes carbonation processes [10]. Therefore, carbonating $\mathrm{CO}_{2}$ requires alkali and alkaline-earth hydroxides, which can be found in combustion ashes [2].

Other authors, such as Chang et al. [9], Eloneva et al. [11], Lombardi et al. [12], Montes-Hernandez et al. [13] and Olajire [14], dealt with the same topic, but examined other types of ash and investigated their suitability for carbonation. These authors performed batch, flow and fixed bed experiments to determine the carbonation efficiency (CE) of their ashes.

The carbonation of $\mathrm{CO}_{2}$ has three major advantages. First, the stability of the main process product $\left(\mathrm{CaCO}_{3}\right)$ is high. The mineral formed is naturally stable, meaning $\mathrm{CO}_{2}$ cannot be re-emitted under ambient conditions [14,15]. Second, the cost efficiency is high. The reaction is exothermic with no need for additional energy input, and in an aqueous medium the reaction will proceed autonomously, e.g., without expensive catalysers [16]. Third, the high availability of ash as a by-product of solid fuel combustion is advantageous [11]. In addition, ashes and emissions from energy generation occur in the same place, reducing the need for transportation.

The amount of wood ash from wood waste combustion in Germany was approximately 320,000 metric tons in 2016 [17,18]. Through combustion, the predominant fraction of wood is converted into the gaseous phase. The remaining mass $(0.1-5 \%,[19])$ mainly consists of ash, depending on the wood type and on the efficiency of the combustion. In general, ash can be separated into bottom ash, which is collected at the bottom of the furnace, and fly ash, which is collected by cyclone separators and/or filter technologies. Heavy metal contents are significantly higher in the fly ash fraction, which complicates or excludes this fraction from later use as fertilizer [20].

An application area for sequestration of $\mathrm{CO}_{2}$ with wood ashes is the purification of biogas. The average $\mathrm{CO}_{2}$ percentage in biogas is between 30 and 50\% [21]. Especially for small-scale anaerobic digestion (AD) plants, biogas upgrading through $\mathrm{CO}_{2}$ sequestration could be an option to provide a natural gas substitute. For small AD plants, an investment in cost-intensive biogas purification units cannot be justified due to the economy of scale. Only large AD plants are indicated to have the financial flexibility to invest in $\mathrm{CO}_{2}$ absorption technologies, such as pressure swing adsorption and membrane filtration [21]. Another field of application could be the sequestration of $\mathrm{CO}_{2}$ from exhaust gases of combustion processes from solid, liquid and biogenic fuels.

Therefore, the objective of this study was to determine the lab-scale $\mathrm{CE}$ of the $\mathrm{CO}_{2}$ sequestration from product gases with wood ash under ambient conditions. The reactor design was selected to be a low-tech approach to lower future implementation costs. Additionally, the influence of different solid-liquid ratios on the overall performance of carbonation was examined. Based on the German Fertilizer Ordinance (Düngemittelverordnung) [22], utilisation potentials of carbonated wood ash (e.g., as fertilizer for agriculture and forestry) are discussed [22]. Furthermore, the hazardousness of the process water for discharging into sewage or water bodies is evaluated.

\section{Materials and Methods}

All analytics were performed in the laboratory of the University of Applied Forest Sciences Rottenburg in Germany. 


\subsection{Preparation of Wood Ash and Carbonation Methods}

The bottom ash used in this study was a by-product of a grate-fired furnace from a full-scale wood combustion heat and power plant in southern Germany, using a mixture of $50 \%$ lignocellulosic residue materials (road side wood, forest residue wood and landscape management material) and 50\% waste wood (class A1 and A2). The samples used in this study were individually obtained from a dried $10 \mathrm{~kg}$ sample that was provided within another study [23]. Prior to the sample extraction, the $10 \mathrm{~kg}$ sample was mixed thoroughly to ensure an even distribution. The wood ash was neither sieved nor grinded additionally. The particle size was estimated to vary from 0.25 to $1.00 \mathrm{~mm}$. Further information on the bottom wood ash particle size distribution can be found in Tejada et al. [23].

Two test series, batch reactor (BR) and flow reactor (FR), each with four repetitions for the mixing ratios 1:20 (50 $\mathrm{g}$ ash), 1:15 (66.6 $\mathrm{g}$ ash) and 1:10 (100 $\mathrm{g}$ ash) of wood ash with $1 \mathrm{~L}$ of tap water, were performed at standard ambient temperature and pressure conditions (SATP).

The carbonation reaction time is between a few seconds and $15 \mathrm{~min}$ depending on the inner surface, the porosity and the size of the $\mathrm{CaO}$ primary crystal contained in the ash [24]. It was not possible to determine these parameters with the available laboratory equipment, and in consequence, it was not possible to estimate the reaction time of the carbonation reaction based on the respective raw material properties. Therefore, as a preparation, the slurries were stirred for $20 \mathrm{~min}$ to ensure that the quicklime $(\mathrm{CaO})$ in the wood ash had enough time to react to slaked lime $\left(\mathrm{Ca}(\mathrm{OH})_{2}\right)$. To prevent the sedimentation of the wood ash particles, the slurry was stirred with a magnetic stirrer at $700 \mathrm{rpm}$.

The batch series (batch method) tested the influence of the solid to liquid ratio on the carbonation process (Figure 1A). The reactor had a volume of $2000 \mathrm{~mL}$. Prior to the experiment, $510 \mathrm{~mL}$ of air at $10^{5} \mathrm{~Pa}$ was pumped out of the reactor. The air from the reactor was pumped into the measuring cylinder. The measuring cylinder contained saturated sodium chloride solution as the confining liquid, which compressed the air because of hydrostatic pressure in the measuring cylinder. The resulting volume of the air was $500 \mathrm{~mL}$ at $1.02 \times 10^{5} \mathrm{~Pa}$. This process created negative pressure in the reactor. The valve between the reactor and cylinder was closed and the air released. Subsequently, $500 \mathrm{~mL}$ of pure $\mathrm{CO}_{2}$ from a $\mathrm{CO}_{2}$ gas cylinder was filled into the measuring cylinder at $1.02 \times 10^{5} \mathrm{~Pa}$. The valve between cylinder and reactor was opened again to suck the $\mathrm{CO}_{2}$ into the wood ash-water slurry. The $\mathrm{CO}_{2}$-containing gaseous phase was circulated with the aim of increasing the slurry's contact surface using a peristaltic pump. To enlarge the contact surface between $\mathrm{CO}_{2}$ and the water-ash slurry, the gaseous phase had to pass through a diffusor. The carbonation led to a reduction in the gaseous volume, which caused a pressure drop in the reactor. After a reaction time of one hour, the experiment was stopped, and a paper filter with an average retention capacity of 4-12 $\mu \mathrm{m}$ filtered the slurry.

The flow test series (flow method) focused on the sequestration evaluation under dynamic conditions, which resembled the dynamic conditions of a flue gas or biogas stream. The testing conditions and preparation were the same as in the batch series, but the experimental setup was reconstructed to operate as a flow reactor with an open valve to prevent a pressure increase (Figure 1B). The volumetric flow rate was set to $120 \mathrm{~mL}$ per minute. $\mathrm{CO}_{2}$ entered the slurry through the left gas line coming from the measuring cylinder: $7200 \mathrm{~mL}$ of $\mathrm{CO}_{2}$ was discharged into the slurries. This procedure was chosen to provide as much of the reactants as possible for the carbonation, to show their maximum CEs.

For further analysis, the carbonated wood ash samples and a none-carbonated reference sample were dried with a drying cabinet (UNP 700, Memmert, Schwabach, Germany) at $105^{\circ} \mathrm{C}$ for about $24 \mathrm{~h}$ according to ISO 18134-1: [25].

\section{2. pH-Value Determination and Elemental Analysis}

As an indicator for the reaction progress, the $\mathrm{pH}$-value was determined prior and after the experiments in accordance with standard procedures (EN 15933: [26]-1) with a pH-Meter (pH 3310 ProfiLine by Xylem Analytics, Weilheim, Germany). 


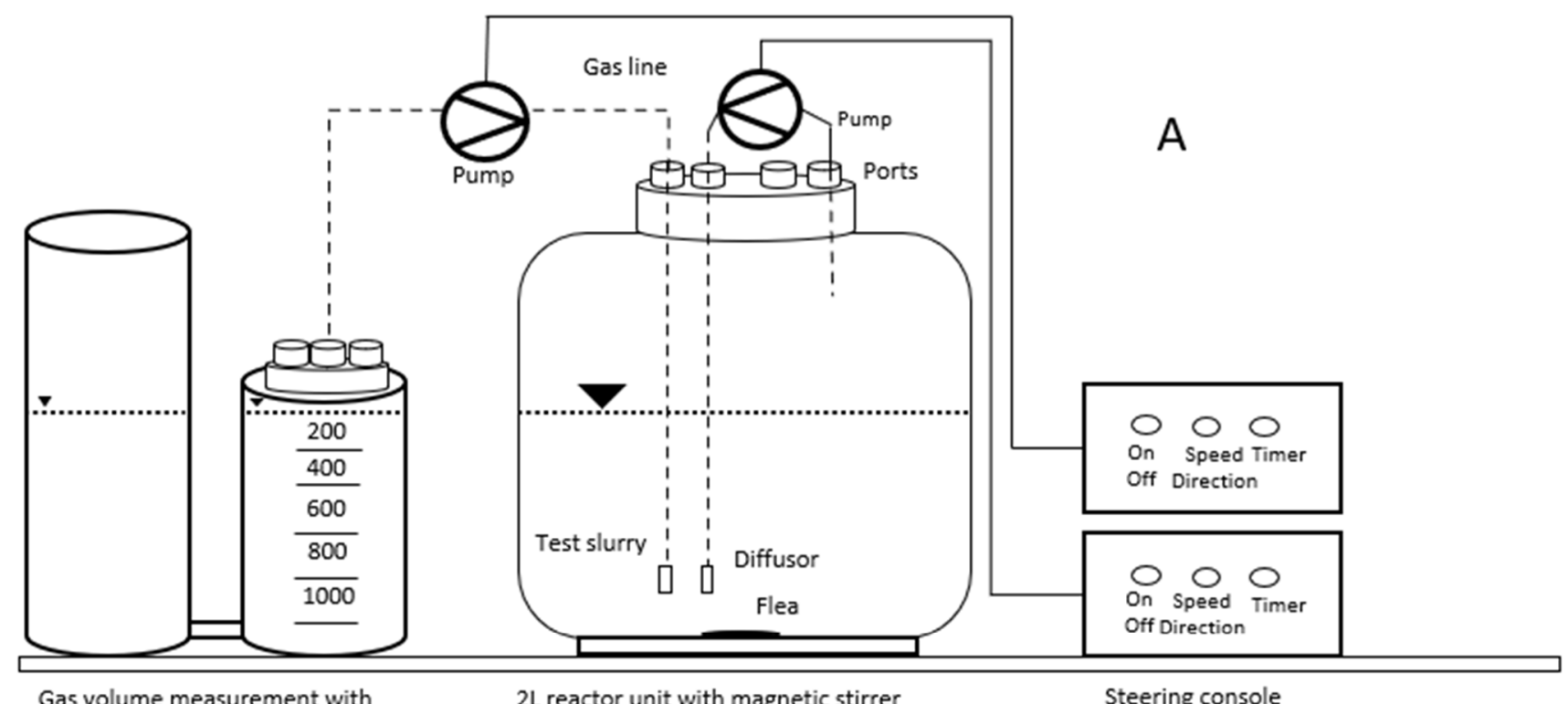

Gas volume measurement with confining liquid

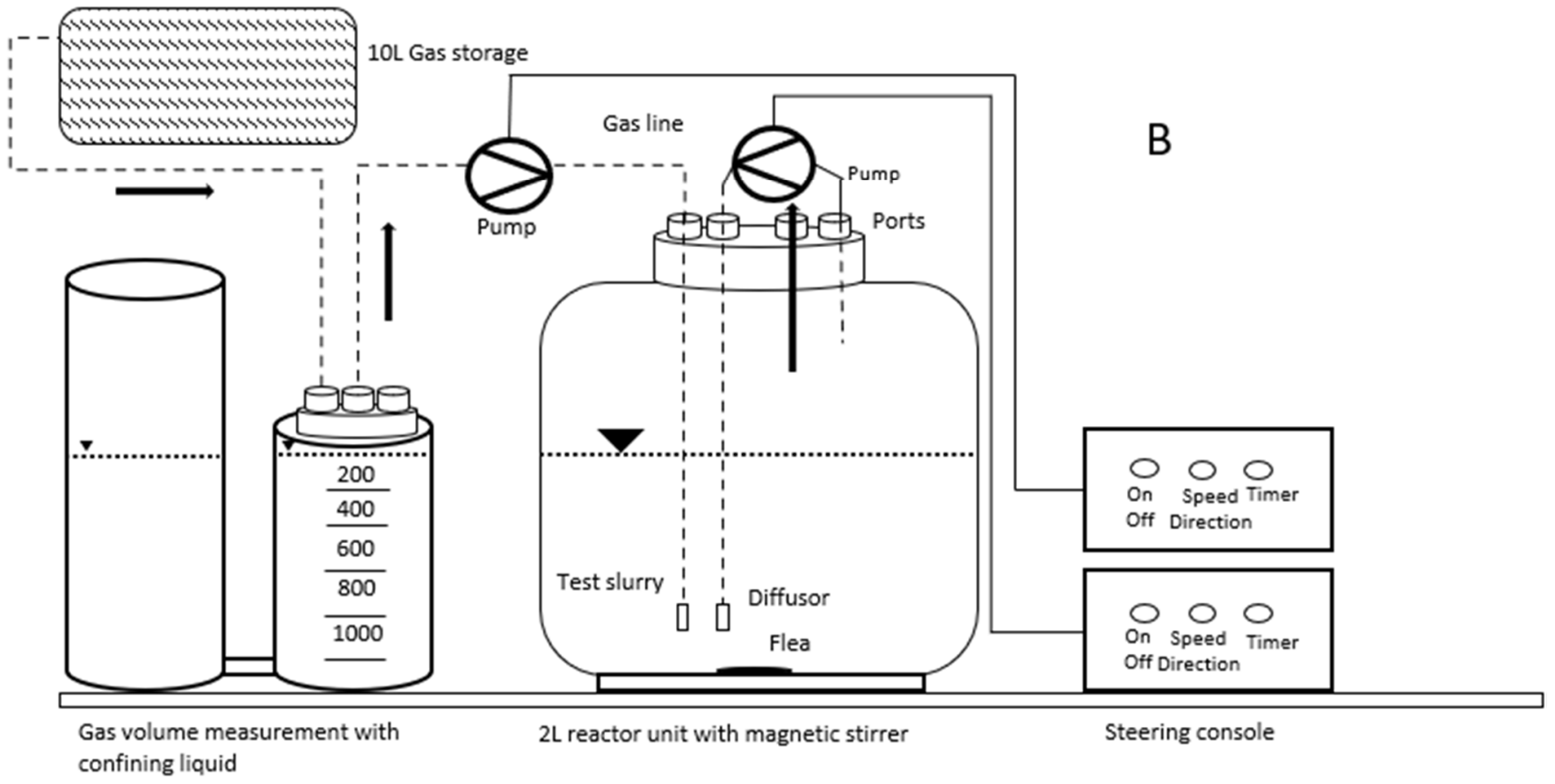

Figure 1. Schemes of the experimental batch and flow setup. (A) The batch run (BR). (B) The flow run (FR). The empty port on FR was used as an exit valve to provide a free flow; gas flow is indicated by arrows.

The dried samples and the filtered process waters were prepared for inductively coupled plasma atomic optical emission spectroscopy (ICP-OES) analysis with a preceding microwave digestion according to ISO 16967: [27]-07 and ISO 16968: [28]-09 (Multiwave GO 3000 Anton Paar Ltd., Ostfildern-Scharnhausen, Germany). For each dry sample, $300 \mathrm{mg}$ was transferred into $50 \mathrm{~mL}$ Teflon vessels and combined with $1 \mathrm{~mL} \mathrm{H}_{2} \mathrm{O}_{2}$. After a reaction time of $5 \mathrm{~min}, 1.5 \mathrm{~mL} \mathrm{HNO}_{3}$ supra quality (69\%, Merck, Darmstadt, Germany) was added, followed by another $1.5 \mathrm{~mL} \mathrm{HNO}_{3}$ and $1 \mathrm{~mL} \mathrm{HCl}$ supra quality (35\%, Roth, Karlsruhe, Germany) $30 \mathrm{~min}$ later. After a reaction time of $24 \mathrm{~h}$ in closed vessels, $6 \mathrm{~mL}$ of $\mathrm{HCl}$ was added before microwave digestion (Multi-wave GO 3000 Anton Paar, Graz, Austria) at $190{ }^{\circ} \mathrm{C}$ for $40 \mathrm{~min}$ with a heat ramping of $12.6^{\circ} \mathrm{C} / \mathrm{min}$. The digested residues were sized to $50 \mathrm{~mL}$ with aqua bi-dest. and analysed with the ICP-OES system (Spectro Blue 3000 spectro/Aemtek Ltd., Kleve, Germany). This allowed to determine the content 
of minor and trace elements in ash and process water. The results were used to estimate the content of relevant oxides.

To determine the total mass of the sequestered $\mathrm{CO}_{2}$ and $\mathrm{CE}$, the dried wood ashes from the batch and flow experiments and the uncarbonated ash samples were analysed in a total organic carbon analyser (Primacs ${ }^{\mathrm{SNC}-100}$ by Scalar, Breda, Netherlands). The amount of total inorganic carbon (IC) was measured by the acidification of the sample. Inorganic carbon reacts with $\mathrm{CO}_{2}$ and can thus be detected. To measure the total carbon (TC) amount, the sample was incinerated at $1200{ }^{\circ} \mathrm{C}$. Subsequently, the amount of $\mathrm{C}$ contained in the sample can be measured by detecting the amount of produced $\mathrm{CO}_{2}$ through complete combustion. The total organic carbon (TOC) was calculated by subtracting IC from TC [29]. This measuring process follows the operating instructions [30,31]. Every batch and flow experiment at each mixing ratio was indicated with four test runs. The ash from every test run was determined in quadruplicate.

\subsection{Carbonation Efficiency}

The $\mathrm{CE}$ was defined by the percentage of sequestered $\mathrm{CO}_{2}$ compared to the theoretical maximum that could be sequestered with the used wood ash. The theoretical maximum was determined with the Steinour equation $\left(\% \mathrm{StCO}_{2}\right)$, which is presented in Equation (2) [32]. The formula contains main alkali and alkaline-earth oxides in $\% w / w$ that influence carbonation. This ratio allowed a direct comparison of different materials and methods for carbonation.

$$
\% \mathrm{StCO}_{2}=0.785\left(\mathrm{CaO}-0.7 \mathrm{SO}_{3}\right)+1.091 \mathrm{MgO}+0.935 \mathrm{~K}_{2} \mathrm{O}+1.420 \mathrm{Na}_{2} \mathrm{O}
$$

Starting with Equation (2), the CE was calculated with Equation (3) [33]. This equation introduces an efficiency factor $\eta\left(\mathrm{CO}_{2}\right)$ for the carbonation.

$$
\eta\left(\mathrm{CO}_{2}\right)=\frac{\% \mathrm{CO}_{2}}{\% \mathrm{StCO}_{2}}
$$

where $\% \mathrm{CO}_{2}$ is the relative amount of $\mathrm{CO}_{2}$ that was sequestered and $\% \mathrm{StCO}_{2}$ is the maximum relative amount that could be sequestered according to Equation (2).

\section{Results}

\subsection{Results for Batch and Flow Carbonation Experiments}

Figure 2 shows the results of the batch reactor series. For BR 1:20, the CE was at $9.9 \%$, and for BR 1:10 it was halved (4.08\%). The amount of $\mathrm{CO}_{2}$ in BR 1:20 was the same as in BR 1:10, but it was twice the amount of ash. Therefore, the efficiency was halved at the 1:10 ratio. That means the $\mathrm{CE}$ behaves approximately proportionally to the wood ash to water ratio if the amount of $\mathrm{CO}_{2}$ remains the same. However, the standard deviation of the fourth run was higher compared to those of the first three runs.

The results of the flow experiments can be seen in Figure 3. The average CE differed from $14.88 \%$ for mixing ratio $1: 20$ to $17.45 \%$ for the mixing ratio $1: 15$. The maximum CE can be seen for test run 2 (FR 1:10), 27.86\%; and the lowest CE for run 4 (FR 1:10), 10.46\%. For the ash to water mixing ratio FR 1:10, the highest variability was observed. Generally speaking, Figure 3 shows an overall average CE of approximately $15 \%$. It can be seen that a lower amount of ash did not result in a remarkably lower $\mathrm{CE}$. The $\mathrm{CE}$ did not rise drastically with more ash used in the experiment.

\subsection{Content of Minor and Trace Elements in the Process Products}

The examination of the carbonated wood ash through ICP-OES showed the relevant minor and trace elements considered in the German Fertilizer Ordinance [22], and we present them in Table 1. Elements not shown in Table 1 were below the detection limit or were not listed as contaminants relevant for application as fertilizer. For instance, relevant 
elements that were below detection limit were $\mathrm{Cd}$ and $\mathrm{Tl}$. For the non-carbonated ash, all other elements that were not below the detection limit can be seen in Table 2.

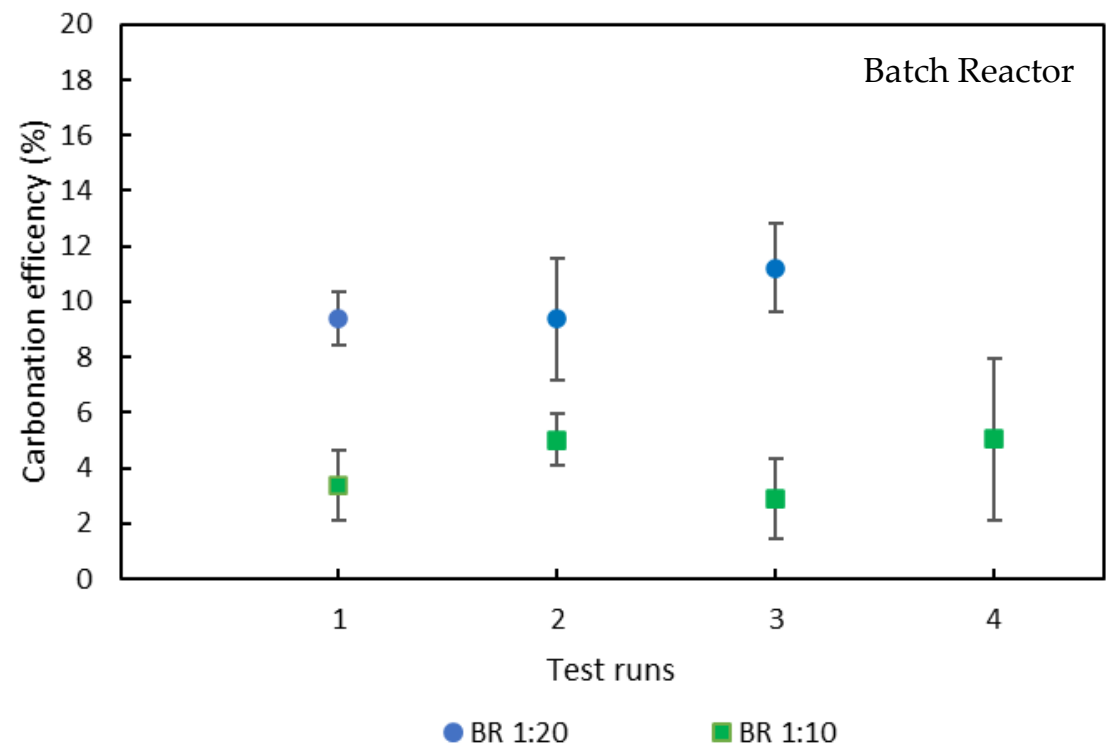

Figure 2. Carbonation efficiency for wood ash in a batch reactor (BR). Mean values \pm standard deviations $(n=4)$. Ash to water mixing ratios 1:20 (blue circles) and 1:10 (green squares). The fourth run of BR 1:20 was discarded because the analysis results were not plausible.

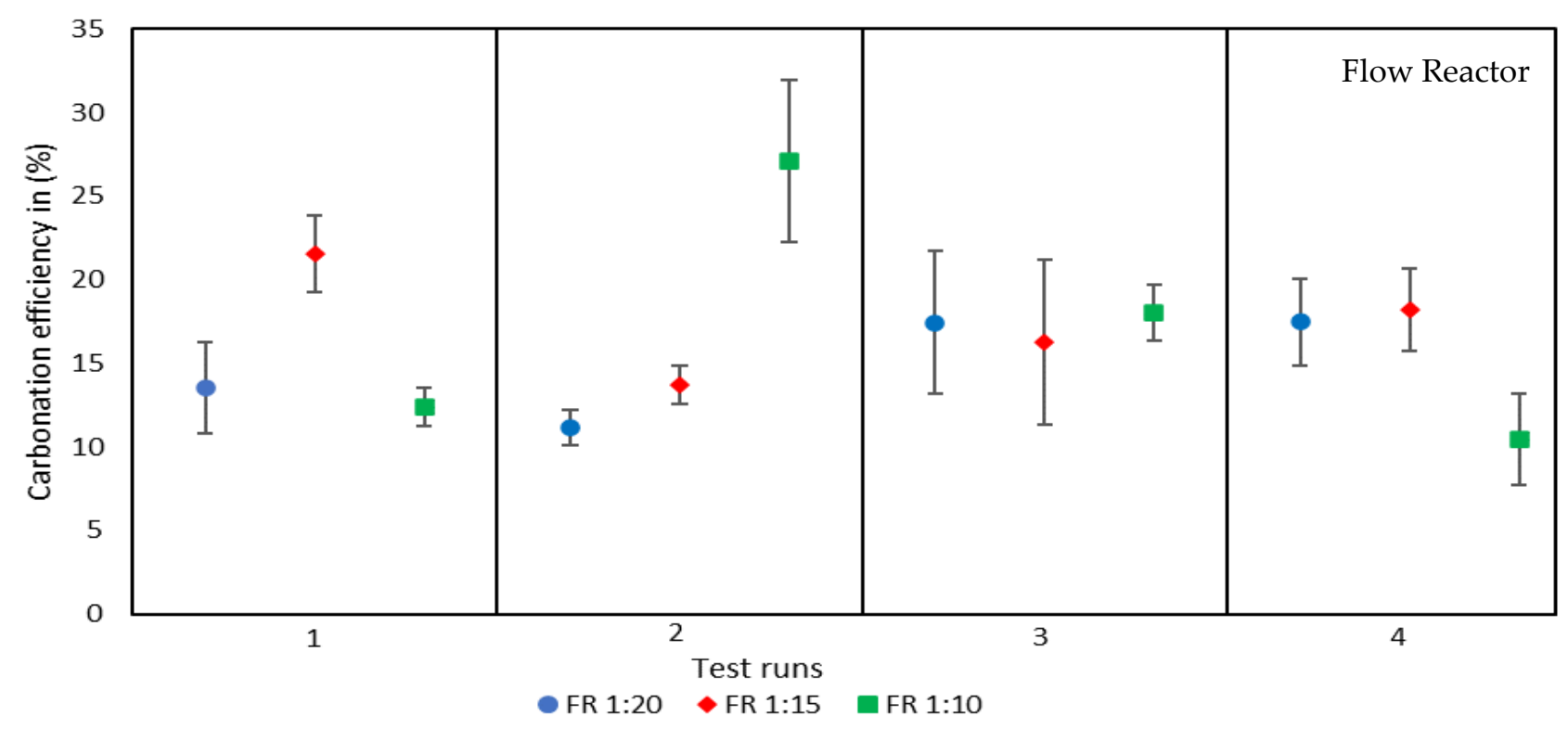

Figure 3. Carbonation efficiency for wood ash in a flow reactor (FR) $(n=4)$, circle (blue) for 1:20, rhombus (red) for 1:15 and square (green) for 1:10 ash to water ratio.

Table 3 shows the detected elements and concentrations relevant for passing the process water into the sewage. $\mathrm{Cd}$ and $\mathrm{Pb}$ were below the detection levels in all samples.

\section{3. $\mathrm{pH}$-Value}

Table 4 shows the $\mathrm{pH}$ values in the reactor for the various test runs. All BR runs showed only small declines in $\mathrm{pH}$ value. This can be explained by the small amount of $\mathrm{CO}_{2}$ used in the BR experiment. The ash still contained non-carbonated hydroxides. In contrast to that, the $\mathrm{pH}$ value was halved in the FR experiment because there were no 
hydroxides left that could be carbonated. FR runs used far more $\mathrm{CO}_{2}$ then necessary to assure the highest possible $\mathrm{CE}$ was reached.

Table 1. Concentrations \pm standard deviations of different minor and trace elements in the carbonated wood ash in mg/kg dry matter (DM): C1 (concentration prior to carbonation) and C2 (concentration after carbonation). Limit value according to the German Fertilizer Ordinance.

\begin{tabular}{cccc}
\hline Element & $\begin{array}{c}\mathrm{C} 1 \\
\left(\mathbf{m g} / \mathbf{k g}_{\text {DM }}\right)\end{array}$ & $\begin{array}{c}\mathrm{C} 2 \\
\left(\mathbf{m g} / \mathbf{k g} \mathbf{D M}_{\mathbf{D}}\right)\end{array}$ & $\begin{array}{c}\text { Limit Value } \\
(\mathbf{m g} / \mathbf{k g}\end{array}$ \\
\hline $\mathrm{Cu}$ & $16.03 \pm 0.010$ & $78.61 \pm 33.43$ & 2000 \\
$\mathrm{Zn}$ & $370.1 \pm 0.002$ & $465.8 \pm 47.68$ & - \\
$\mathrm{B}$ & $106.4 \pm 4.19$ & $93.64 \pm 14.52$ & - \\
$\mathrm{Mg}$ & $13,690 \pm 1513$ & $12,250 \pm 635.4$ & - \\
$\mathrm{Ni}$ & $31.36 \pm 2.04$ & $32.07 \pm 2.04$ & 150 \\
$\mathrm{~Pb}$ & $3.04 \pm 2.65$ & $22.97 \pm 7.63$ & - \\
$\mathrm{Cr}$ & $65.15 \pm 0.001$ & $63.32 \pm 15.93$ & - \\
$\mathrm{Ca}$ & $118,000 \pm 7599$ & $111,600 \pm 9911$ & \\
\hline
\end{tabular}

Table 2. Concentrations \pm standard deviations of different minor and trace elements in the noncarbonated wood ash in $\mathrm{mg} / \mathrm{kg}$ dry matter (DM): C1 (concentration prior carbonation).

\begin{tabular}{cc}
\hline Element & $\begin{array}{c}\mathbf{C 1} \\
(\mathbf{m g} / \mathbf{k g} \mathbf{D M})\end{array}$ \\
\hline $\mathrm{Na}$ & $2910 \pm 195.7$ \\
$\mathrm{Al}$ & $29,980 \pm 2014$ \\
$\mathrm{~K}$ & $34,020 \pm 1786$ \\
$\mathrm{Mn}$ & $913.1 \pm 72.07$ \\
$\mathrm{Li}$ & $46.26 \pm 5.681$ \\
$\mathrm{Ba}$ & $933.0 \pm 213.0$ \\
$\mathrm{Ga}$ & $50.50 \pm 4.764$ \\
$\mathrm{Sr}$ & $222.2 \pm 9.301$ \\
$\mathrm{Fe}$ & $22,560 \pm 2165$ \\
\hline
\end{tabular}

Table 3. Concentrations \pm standard deviations of detected minor and trace elements in $\mathrm{mg} / \mathrm{L}$ in process water: $\mathrm{C} 1$ (concentration prior carbonation) and $\mathrm{C} 2$ (concentration after carbonation). Limit value according to the German Sewage Water Law.

\begin{tabular}{cccc}
\hline Element & $\begin{array}{c}\mathrm{C} 1 \\
(\mathbf{m g} / \mathrm{L})\end{array}$ & $\begin{array}{c}\mathrm{C} 2 \\
(\mathbf{m g} / \mathbf{L})\end{array}$ & $\begin{array}{c}\text { Limit Value } \\
(\mathbf{m g} / \mathbf{L})\end{array}$ \\
\hline $\mathrm{Cr}$ & $0.002 \pm<0.001$ & $0.095 \pm 0.032$ & 0.5 \\
$\mathrm{Ni}$ & $0.033 \pm<0.001$ & $0.029 \pm 0.01$ & 0.5 \\
$\mathrm{Cu}$ & $0.105 \pm<0.001$ & $0.014 \pm 0.005$ & 0.5 \\
$\mathrm{Zn}$ & $0.317 \pm 0.005$ & $0.112 \pm 0.042$ & 1.0 \\
\hline
\end{tabular}

Table 4. $\mathrm{pH}$ values for each test run presented with mean values \pm standard deviations (SD) for the batch run (BR) and for the flow run (FR); the ratios of 1:20, 1:15 and 1:10 describe the mixing ratios of water and ash for the test runs; $\mathrm{pH} 1$ (prior carbonation), $\mathrm{pH} 2$ (after carbonation).

\begin{tabular}{ccc}
\hline Test Run & pH 1 & pH 2 \\
\hline BR 1:20 & $12.55 \pm 0.04$ & $12.03 \pm 0.27$ \\
BR 1:15 & $12.54 \pm 0.08$ & $12.29 \pm 0.09$ \\
BR 1:10 & $12.67 \pm 0.06$ & $12.55 \pm 0.12$ \\
FR 1:20 & $12.37 \pm 0.11$ & $6.28 \pm 0.10$ \\
FR 1:15 & $12.28 \pm 0.15$ & $6.26 \pm 0.10$ \\
FR 1:10 & $12.40 \pm 0.09$ & $6.33 \pm 0.22$ \\
\hline
\end{tabular}




\section{Discussion of Results}

\subsection{Effects of Solid to Liquid Ratio on Carbonation}

As seen in Figure 2, the concentration of wood ash in the slurries doubled from 1:20 to $1: 10$, and the CE was approximately reduced by $50 \%$. That means that the reaction rate stayed the same independent of the water to ash ratio and depending on how much reactant was available. This is consistent with the data from previous studies $[34,35]$. Regarding flow experiments, an ash to water ratio of 1:15 seemed to provide the best average CE compared to the other test series (Figure 3). It could not be determined whether this was coincidental or if the ratio is most suitable for carbonation. Generally speaking, the experiments were observed to perform better and to be faster when operating under flow conditions.

\subsection{Carbonation Efficiency of Wood Ash and Usage of Carbonated Ash and Process Water}

The results for $C E$ can be seen in Figure 3. The average CE was $16.44 \%$. Compared to previous studies, this figure seems to be low [33]. Comparing testing conditions and experimental setups from previous studies with this study, it is obvious that under high pressure and at high temperatures, the $\mathrm{CE}$ is also higher. Pressure and temperature increase the kinetics of a reaction; hence, the $\mathrm{CE}$ is increased under more severe reaction conditions [13]. An increase in temperature has two opposing effects. On the one hand, it increases the reaction rate, and on the other hand, it decreases the solubility of $\mathrm{CO}_{2}$ and $\mathrm{Ca}(\mathrm{OH})_{2}$. Therefore, it is not sufficient to just increase temperature, which corresponds with the findings in literature [36]. A combination of high pressure and temperature will consequently increase $\mathrm{CE}$. The aim of this study was to perform carbonation tests under ambient conditions for a later low-tech carbonation plant. Therefore, a lower CE would be acceptable. Lombardi et al. [12] proved in a fixed bed reactor that $\mathrm{CE}$ can be significantly higher for wood ash, but the ash would not be suitable for a later use as fertilizer.

To date, no special act regulates the concentration of minor and trace elements in process water from carbonation processes, but regarding a possible use of carbonation for flue gas purification, the limit values for water from gas purification can be taken as references.

Equation (2) defines the maximum theoretical mass of $\mathrm{CO}_{2}$ that can be sequestered with an arbitrary substance. This mass of $\mathrm{CO}_{2}$ mainly depends on the alkali and earth alkaline oxides in the equation. Equation (2) was also used in other publications [33]. CE, as it is defined in this work, is the quotient resulting from the sequestered amount of $\mathrm{CO}_{2}$ divided by the theoretical maximum of $\mathrm{CO}_{2}$ that could be sequestered. Another approach could be to compare the amount of $\mathrm{CO}_{2}$ sequestered to the absolute amount of ash used. The former method was chosen because on the one hand, it shows if an experimental setup is designed well, and on the other hand, it creates results with better comparability to the results published on other ashes. Minor components and trace elements of the carbonated wood ash can be seen in Table 1. Other relevant components could not be detected due to their fugacity at higher temperatures or were below the detection limit. All values except $\mathrm{Mg}$ were below their specific labelling requirements and limit values, if existent. This could promote the use as a fertilizer for agriculture and forestry, as Pasquali et al. [37] suggested. The German Fertilizer Ordinance [22] intends the use of uncarbonated wood ash for chalking forests. It is especially mentioned that only bottom ashes from the combustion of untreated natural plant components can be used for this purpose. The absence of a limit value for $\mathrm{Cr}$ is only valid if it is used for chalking forests. The same applies for the limit value of $\mathrm{Cu}$. Additionally, the carbonated wood ash must be granulated while being free of dust [22]. It cannot be derived from the German Fertilizer Ordinance if there could be another field of application for the carbonated ash besides chalking. Furthermore, it must be analysed if the carbonated wood ash contains higher amounts of macro- and micronutrients for a possible use as fertilizer.

As can be seen in Table 2, the concentrations in the water did not exceed the given limit values. Baumgarten et al. [38] studied the same ash and applied the same limit values. The 
results from both studies correspond with each other. Adding to the shown elements, there are regulations for $\mathrm{Cd}, \mathrm{Pb}$ and $\mathrm{Hg}$, but these were below detection levels. It is important to mention that the concentrations have to be measured prior to a possible dilution.

\subsection{Impacts on Practice}

Considering that wood ash is a residue from combustion of solid-state fuels that is usually deposited, a cascade use would be favourable in the sense of a circular economy. A possible field of application for this technology could be the sequestration of $\mathrm{CO}_{2}$ from the flue gas at small to medium wood fired heat or heat and power plants. At the moment, the ash resulting from combustion has to be disposed of expensively. Direct application of the ash for $\mathrm{CO}_{2}$-sequestration on site could deliver a series of benefits. Biomass ashes are a low-cost medium, which does not need to be transported to the plant and can be used for a low-tech sequestration approach. Plant operators could tap into additional revenue streams by producing and marketing net negative $\mathrm{CO}_{2}$ emissions. If legal requirements are met, the carbonated wood ash can be sold as a fertilizer, avoiding high costs for ash disposal and effectively binding carbon within the soil [39].

Another implementation could be the sequestration of $\mathrm{CO}_{2}$ from smaller volume flows of biogas. Biogas contains between 50 and 70\% of $\mathrm{CH}_{4}$ [40] and between 25 and $45 \%$ of $\mathrm{CO}_{2}$ [41]. This $\mathrm{CO}_{2}$ is normally sequestered with pressure swing adsorption, amin washing or pressurised water washing. The sequestration plants are usually available for a minimum volume flow of $250 \mathrm{~m}^{3} / \mathrm{h}$ at standard conditions $\left(0{ }^{\circ} \mathrm{C}\right.$ and $\left.1013.25 \mathrm{hPa}\right)$. Smaller upgrading plants are not cost efficient, and therefore, not interesting for operators of smallscale AD plants [21]. This niche could be filled by a wood ash sequestration plant. Its operating costs are likely to be lower than those of conventional plants because wood ash is a residue that has to be disposed of expensively. Plant operators would produce a fertilizer which could be used for agricultural and forestry. Another biogas-related use could be the upgrading of biogas from micro-AD plants in developing countries to increase the calorific value of the biogas. A thermal power station with an annual wood consumption of 50,000 metric tons with an ash content of $1 \%$ produces 500 metric tons of ash per year. A carbonation process with a CE equal to the results in this study could approximately sequester 12.5 metric tons of $\mathrm{CO}_{2}$.

\section{Conclusions}

This study confirmed the result of previous studies, showing that the ash to water ratio has no major impact on the carbonation process. Nevertheless, more ash in the mixture increases the amount of sequestered $\mathrm{CO}_{2}$. Regarding the necessity of water as a reactant for reaction of $\mathrm{CaO}$ to $\mathrm{Ca}(\mathrm{OH})$ and its support for the actual carbonation, a sufficient water supply is necessary.

In terms of process efficiency, wood ash reached a CE of approximately $16 \%$. This means the wood ash can sequester $16 \%$ of the theoretical maximum mass, which could be sequestered according to the stoichiometry of the carbonation reaction. This is less than other industrial ashes examined in previous studies, but considering its intended use and the cost effective testing conditions, this approach could be favourable for a practical application. With few modifications, especially higher pressure and temperature, the results could be improved. A longer reaction time might increase the $\mathrm{CE}$ as well. This could be a focus of further research.

For the carbonated wood ash an application as fertilizer would be feasible. This requires that the wood ash originates from the combustion of untreated wood. The fertilizer could be used for chalking in agriculture and forestry. The carbonation of ash is an effective CCS or BECCS method to tackle climate change and to lower atmospheric $\mathrm{CO}_{2}$ concentrations. A potential use of the process water was not reviewed, but it can be passed into water bodies or sewage after a dilution. 
The next step following the experiments presented in this study should be a large-scale test to confirm the results under real-life operating conditions for AD plants and for the sequestration of $\mathrm{CO}_{2}$ from flue gases.

Author Contributions: Conceptualisation, R.K., G.S., J.P. and S.P. (Stefan Pelz); methodology, R.K., G.S. and J.P.; validation, R.K., G.S., J.P., S.P. (Sebastian Paczkowski) and J.M.; formal analysis, R.K., G.S. and J.M.; investigation, R.K.; writing—original draft preparation, R.K. and G.S.; writing—review and editing, R.K., G.S., S.P. (Sebastian Paczkowski), J.P. and J.M.; visualisation, R.K., G.S., J.P. and J.M.; supervision, J.P., S.P. (Stefan Pelz) and J.M., project administration, J.P. and S.P. (Stefan Pelz). All authors have read and agreed to the published version of the manuscript.

Funding: This research received no external funding.

Institutional Review Board Statement: Not applicable.

Informed Consent Statement: Not applicable.

Data Availability Statement: The data presented in this study are available on request from the first and corresponding authors.

Conflicts of Interest: The authors declare no conflict of interest.

\section{References}

1. Pachauri, R.K.; Mayer, L. Climate Change 2014 Synthesis Report; IPCC: Geneva, Switzerland, 2015.

2. National Academies Press. Negative Emissions Technologies and Reliable Sequestration: A Research Agenda; National Academies Press: Washington, DC, USA, 2019; ISBN 9780309484534.

3. European Commission. The European Green Deal; European Commission: Brussels, Belgium, 2019.

4. Fajardy, M.; Mac Dowell, N. Can BECCS deliver sustainable and resource efficient negative emissions? Energy Environ. Sci. 2017, 10, 1389-1426. [CrossRef]

5. Herzog, H.J. Carbon Capture; MIT Press: Cambridge, UK, 2018; ISBN 9780262348867.

6. Geden, O.; Schenuit, F.; Stiftung Wissenschaft und Politik. Unkonventioneller Klimaschutz; Stiftung Wissenschaft und Politik: Berlin, Germany, 2020. [CrossRef]

7. Smith, P. Soil carbon sequestration and biochar as negative emission technologies. Glob. Chang. Biol. 2016, 22, 1315-1324. [CrossRef] [PubMed]

8. Muratori, M.; Calvin, K.; Wise, M.; Kyle, P.; Edmonds, J. Global economic consequences of deploying bioenergy with carbon capture and storage (BECCS). Environ. Res. Lett. 2016, 11, 095004. [CrossRef]

9. Chang, E.-E.; Pan, S.-Y.; Chen, Y.-H.; Chu, H.-W.; Wang, C.-F.; Chiang, P.-C. $\mathrm{CO}_{2}$ sequestration by carbonation of steelmaking slags in an autoclave reactor. J. Hazard. Mater. 2011, 195, 107-114. [CrossRef] [PubMed]

10. Stark, J.; Wicht, B. Dauerhaftigkeit von Beton; Springer: Berlin/Heidelberg, Germany, 2013; ISBN 978-3-642-35277-5.

11. Eloneva, S.; Teir, S.; Salminen, J.; Fogelholm, C.-J.; Zevenhoven, R. Fixation of $\mathrm{CO}_{2}$ by carbonating calcium derived from blast furnace slag. Energy 2008, 33, 1461-1467. [CrossRef]

12. Lombardi, L.; Costa, G.; Spagnuolo, R. Accelerated carbonation of wood combustion ash for $\mathrm{CO}_{2}$ removal from gaseous streams and storage in solid form. Environ. Sci. Pollut. Res. Int. 2018, 25, 35855-35865. [CrossRef] [PubMed]

13. Montes-Hernandez, G.; Pérez-López, R.; Renard, F.; Nieto, J.M.; Charlet, L. Mineral sequestration of CO(2) by aqueous carbonation of coal combustion fly-ash. J. Hazard. Mater. 2009, 161, 1347-1354. [CrossRef] [PubMed]

14. Olajire, A.A. A review of mineral carbonation technology in sequestration of $\mathrm{CO}_{2}$. J. Pet. Sci. Eng. 2013, 109, 364-392. [CrossRef]

15. Bertos, M.F.; Simons, S.J.R.; Hills, C.D.; Carey, P.J. A review of accelerated carbonation technology in the treatment of cement-based materials and sequestration of $\mathrm{CO}_{2}$. J. Hazard. Mater. 2004, 112, 193-205. [CrossRef]

16. Lackner, K.S.; Wendt, C.H.; Butt, D.P.; Joyce, E.L.; Sharp, D.H. Carbon dioxide disposal in carbonate minerals. Energy 1995, 20, 1153-1170. [CrossRef]

17. Mühlenhoff, J.; Kajimura, R.; Boenigk, N.; Witt, J.; Horschig, T. Holzenergie in Deutschland Status Quo und Potenziale No. 82, Berlin. 2017. Available online: https://www.unendlich-viel-energie.de/media/file/2121.82_Renews_Spezial_Holzenergie_Aug2 017.pdf (accessed on 30 June 2020).

18. Kaltschmitt, M.; Hartmann, H.; Hofbauer, H. Energie aus Biomasse; Springer: Berlin/Heidelberg, Germany, 2016; ISBN 978-3-662-47437-2.

19. Deutsches Institut für Normung (DIN). Solid Biofuels_Fuel Specifications and Classes_Part 1: General Requirements; (ISO 172251:2021); Beuth Verlag GmbH: Berlin, Germany, 2021.

20. Marutzky, R.; Seeger, K. Energie aus Holz und Anderer Biomasse: Grundlagen, Technik, Emissionen, Wirtschaftlichkeit, Entsorgung, Recht; 1., unveränd. Nachdr; DRW-Verlag Weinbrenner: Leinfelden-Echterdingen, Germany, 2002; ISBN 3871813478.

21. Adler, P.; Billig, E.; Brosowski, A.; Daniel-Gromke, J.; Falke, I.; Fischer, E. Leitfaden Biogasaufbereitung und -Einspeisung, 5th ed.; Vollständig Überarbeitete Auflage; Fachagentur für Nachwachsende Rohstoffe e. V. (FNR): Gülzow-Prüzen, Germany, 2014; ISBN 3000183469 . 
22. Bundesministerium der Justiz und für Verbraucherschutz. German Fertilizer Ordinance (Düngemittelverordnung); DüMV: Berlin, Germany, 2012.

23. Tejada, J.; Wiedenmann, J.; Gall, B.; Kaiser, B.; Greißl, O.; Unterberger, S.; Kappler, A.; Thorwarth, H. Trace element behavior in wood-fueled heat and power stations in terms of an urban mining perspective. Fuel 2020, 267, 116887. [CrossRef]

24. Marbun, B. Kinetik der Hydratation von $\mathrm{CaO}$ und MgO. Ph.D. Thesis, Technischen Universität Clausthal, Clausthal, Germany, 2006

25. Deutsches Institut für Normung (DIN). Solid Biofuels—Determination of Moisture Content_Oven Dry Method-Part 1: Total Moisture—Reference Method; (ISO 18134-1:2015); Beuth Verlag GmbH: Berlin, Germany, 2015.

26. Deutsches Institut für Normung (DIN). Sludge, Treated Biowaste and Soil-Determination of pH, German version EN 15933:2012; Beuth Verlag GmbH: Berlin, Germany, 2012.

27. Deutsches Institut für Normung (DIN). Solid Biofuels_Determination of Major Elements_Al, $\mathrm{Ca}, \mathrm{Fe}, \mathrm{Mg}, \mathrm{P}, \mathrm{K}, \mathrm{Si}, \mathrm{Na}$ and Ti; (ISO 16967:2015); Beuth Verlag GmbH: Berlin, Germany, 2015.

28. Deutsches Institut für Normung (DIN). Solid Biofuels—Determination of Minor Elements; (ISO 16968:2015); Beuth Verlag GmbH: Berlin, Germany, 2015.

29. Schumacher, B. Methods for the Determination of Total Organic Carbon (TOC) in Soils and Sediments; U.S. Environmental Protection Agency: Washington, DC, USA, 2002.

30. Skalar Analytical, B.V. Skalar Methods: Total Carbon/Total Nitrogen; Soil Catnr. P03-001; Skalar Analytical B.V.: Breda, The Netherlands, 2020.

31. Skalar Analytical, B.V. Skalar Methods: Total Inorganic Carbon; General Method Catnr. P05-099; Skalar Analytical B.V.: Breda, The Netherlands, 2020.

32. Steinour, H.H. Some effects of carbon dioxide on mortars and concrete-discussion. J. Am. Concr. Inst. 1959, 30, 905-907.

33. González, A.; Moreno, N.; Navia, R. $\mathrm{CO}_{2}$ carbonation under aqueous conditions using petroleum coke combustion fly ash. Chemosphere 2014, 117, 139-143. [CrossRef] [PubMed]

34. Ji, L.; Yu, H.; Wang, X.; Grigore, M.; French, D.; Gözükara, Y.M.; Yu, J.; Zeng, M. $\mathrm{CO}_{2}$ sequestration by direct mineralisation using fly ash from Chinese Shenfu coal. Fuel Process. Technol. 2017, 156, 429-437. [CrossRef]

35. Dananjayan, R.R.T.; Kandasamy, P.; Andimuthu, R. Direct mineral carbonation of coal fly ash for $\mathrm{CO}_{2}$ sequestration. J. Clean. Prod. 2016, 112, 4173-4182. [CrossRef]

36. Ukwattage, N.L.; Ranjith, P.G.; Yellishetty, M.; Bui, H.H.; Xu, T. A laboratory-scale study of the aqueous mineral carbonation of coal fly ash for $\mathrm{CO}_{2}$ sequestration. J. Clean. Prod. 2015, 103, 665-674. [CrossRef]

37. Pasquali, M.; Zanoletti, A.; Benassi, L.; Federici, S.; Depero, L.E.; Bontempi, E. Stabilized biomass ash as a sustainable substitute for commercial P-fertilizers. Land Degrad. Dev. 2018, 29, 2199-2207. [CrossRef]

38. Baumgarten, B.; Grammer, P.; Ehard, F.; Winkel, O.; Vogt, U.; Baumbach, G.; Scheffknecht, G.; Thorwarth, H. Evaluation of a metal mesh filter prototype with wet regeneration. Biomass Conv. Bioref. 2021. [CrossRef]

39. He, Q.; Shi, M.; Liang, F.; Xu, L.; Ji, L.; Yan, S. Renewable absorbents for $\mathrm{CO}_{2}$ capture: From biomass to nature. Greenh. Gas. Sci. Technol. 2019, 9, 637-651. [CrossRef]

40. Zahoransky, R. Energietechnik; Springer: Wiesbaden, Germany, 2019; ISBN 978-3-658-21846-1.

41. Fachagentur Nachwachsende Rohstoffe e.V. (FNR). Handreichung Biogasgewinnung und -Nutzung; Gülzow-Prüzen, Germany, 2004; ISBN 3000143335. 